\title{
Trending Readings: Virtue vs. Vicious Significance
}

\author{
Simon J. Daniel ${ }^{1}$ \\ ${ }^{1}$ Associate Professor in English, KL University (KLEF), Guntur, Andhra Pradesh, India
}

\begin{abstract}
Reading makes a full man, as Francis Bacon observed. If one needs to sharpen one's intellect, one ought doubtless to take to reading, which is essentially, a virtue. Man, being a composite of the mind and the body, not to speak of the integral dimension of the spirit, even as the physique needs exercise, so does the mind. Reading bequeaths on one, the knowledge of all that is known to man and helps him come to grips with various facets of the world in which we live in. Books, therefore promise alluring journeys into the vicissitudes of life, if only one opens the covers and is willing to embark on a voyage of intellectual emancipation.
\end{abstract}

Keywords: Trending Readings, Virtue vs. Vicious Significance

\section{Introduction}

Reading makes a full man, as Francis Bacon observed. If one needs to sharpen one's intellect, one ought doubtless to take to reading, which is essentially, a virtue. Man, being a composite of the mind and the body, not to speak of the integral dimension of the spirit, even as the physique needs exercise, so does the mind. Reading bequeaths on one, the knowledge of all that is known to man and helps him come to grips with various facets of the world in which we live in. Books, therefore promise alluring journeys into the vicissitudes of life, if only one opens the covers and is willing to embark on a voyage of intellectual emancipation.

Joanne Rowling had once demanded that Coca-Cola, the winner in the race to tie in their products to her film series, donate US\$18 million to the American charity 'Reading Is Fundamental.' Books among her Harry Potter series include: Harry Potter and the Philosopher's Stone (26 June 1997); Harry Potter and the Chamber of Secrets (2 July 1998); Harry Potter and the Prisoner of Azkaban (8 July 1999); Harry Potter and the Goblet of Fire (8 July 2000); Harry Potter and the Order of the Phoenix (21 June 2003); Harry Potter and the Half-Blood Prince (16 July 2005) and Harry Potter and the Deathly Hallows (21 July 2007).

Now, should one go a little further in history, one would notice that Faustus requests such a book in his address to Mephistopheles: "yet fain would I have a book wherein I might behold all spells and incantations, that I might raise up spirits when I please,"(Doctor Faustus) at which Mephistopheles readily obliges, granting him two more on the subject of planets and herbs.

Lucifer himself when he had done with tempting Faustus with the concocted pleasures of hell, as he says to him: "Faustus, in hell is all manner of delight,"(Doctor Faustus), Faustus expresses a desire to see hell and return again, upon which Lucifer gives him a book, asking him to peruse it, promising that he could turn himself into whatever shape he may want to get transformed into:

"FAUSTUS. O, might I see hell, and return again,

How happy were I then!

LUCIFER. Thou shalt; I will send for thee at midnight.

In meantime take this book; peruse it thoroughly, 
And thou shalt turn thyself into what shape thou wilt.

FAUSTUS. Great thanks, mighty Lucifer!” (Doctor Faustus)

While on the one hand, the present generation, the millennials and their preference for team work and shorter work hours, and immediate results and fast response times, facilitated by digital felicity, have scarcely enough time to take to books, would reading generally considered a benign virtue, unsuspectingly bring in a vice-like grip on the minds of our young ones on the other, with books such as billions engrossing JK Rowlings'?

Growing up in today's world, the twenty-first century, identifying pathways and trying to take on the challenges that appear, with fundamental disciplines lost, prompting adaptation to fast changing courses, amidst school violence and sometimes, even lack of state support, as in many countries of the world, forced to long study hours, with expectations increased exponentially, one cannot help noticing that there is nevertheless, an acute lack of appreciation for the beauty and goodness of life. Added to this predicament, are the insinuations to the other side of life, rather unfortunately, through the much-heralded past time of reading.

In the aftermath of the now famous J. K. Rowling 's Harry Potter series of novels that have enraptured the imagination of children all over the globe, is there even a chance for the millennial generation to enjoy in the right way, earthly life bestowed upon by Providence, what with the cursed art of necromancy, so arraigned since Christopher Marlowe's Doctor Faustus, emblazoning itself in startlingly dark tones?

Would the tendency of the digital generation millennials to look for immediate results with fast response times, lead to disastrous consequences, even with the few readers who still consider taking to books a virtue?

Milton, talks of Lucifer who, having 'set himself in glory above his peers, he trusted to have equal'd the most High," (Paradise Lost). The eventual consequence was that "'the Almighty Power hurled him headlong...to bottomless perdition.' (Paradise Lost, Book I).

Unaccepting of defeat, the rebellious spirit in him continues to deter Omnipotence, as Lucifer attempts to fight an indirect war through mankind. "What if we find some enterprise?... the happy seat of some new Race called Man" (Paradise Lost, Book II). The machiavellian protagonist of Paradise Lost plots thus:

"To waste his whole Creation, or possess

All as our own, and drive as we were driven,

The puny habitants, or if not drive,

Seduce them to our Party, that their God

May prove their foe, and with repenting hand

Abolish his own works.” (Paradise Lost, Book II).

Lucifer had an esteemed place high above all creation, as chief of angels, an archangel. However, he was not satisfied with his position, but wanted to soar higher and dethrone Omnipotence Himself. This resulted in his undoing, for such an act of an individual displeases the Creator and would invite sure damnation. This act, of not just defiance against the most High, but an attempt to usurp His office would equal Lucifer's attempt at the same object and would supposedly, isolate, weaken or defeat the Almighty. This unreasonable reasoning of Lucifer's, drunk up in the power and beauty that was given to him, he sets as the objective, for humankind to ensure the wrath of God, which would lead to the sure overthrow of mankind itself. Christopher Marlowe's Doctor Faustus, in similar vein, flaps

"His waxen wings (to) mount above his reach,

And, melting, heavens conspir'd his overthrow;

For, falling to a devilish exercise,

And glutted...with learning's golden gifts,

He surfeits upon cursed necromancy;" (Doctor Faustus, Chorus). 
He launches upon necromancy and magic and envisions himself to be a god, at whose beckoning, all powers would respond.

"These metaphysics of magicians,

And necromantic books are heavenly;

Lines, circles, scenes, letters, and characters; ...

A sound magician is a mighty god:" (Doctor Faustus).

Insinuations to the other side of life, to venture into, is to veritably invoke the displeasure of Omnipotence and lead to damnation. Quite interestingly though, this objective of the Devil has been introduced through the much-heralded past time of reading.

The number of books, that have been written on this cursed art of necromancy that are in circulation today, among children and young adults, is formidable. Equally formidable is the amount of research and the number of secondary writings that have come up on the subject. Some of the books written on necromancy include: Witchcraft Continued: Popular Magic in Modern Europe by Willem De Blécourt; Owen Davies, Manchester University Press, 2004; Thinking with Demons: The Idea of Witchcraft in Early Modern Europe, by Stuart Clark, Oxford University Press, 1999; Witchcraft and Its Transformations, c. 1650-c.1750 by Ian Bostridge, Clarendon Press, 1997; Living Witchcraft: A Contemporary American Coven by Allen Scarboro; Shirley Stave; Nancy Campbell, Praeger Publishers, 1994. There are also comparative studies undertaken between witchcraft practised in different places or periods as in Witchcraft in Tudor and Stuart England: A Regional and Comparative Study, by Alan Macfarlane, Routledge 1999 (2nd edition).

The vicious significance lies in this, that quite like his fall from high acclaim to the lowly depths of grovelling madness, Lucifer attempts at deceiving mankind to test the limits or go beyond the precincts of what is permissible for humans. So, armed with the knowledge of what would in certainty displease Omnipotence and enrage Him to make humanity lose its ultimate goal of life everlasting in eternal bliss to abject eternal damnation.

Among the numerous necromantic books written for young children, apart from the Harry Potter series is one with the title, A Children's Book of Necromancy, published in 2010 by Debrin Case and Darcy Melton. It has for a cover page, two very young girls with at the bottom, a stamp in red that states as an invitation: 'NOT RECOMMENDED FOR CHILDREN.'

The contents of this colouring book include the journey of a little girl who vows to get revenge on a playground bully by raising an army of dead crickets. The book purports to teach its young readers to even raise the dead!

As even Faustus contemplated and attempted, therefore, are these agents, the unconscionable writers of necromantic books, beckoning children to the damned prevarication of necromancy:

'Couldst thou make men to live eternally,

Or, being dead, raise them to life again,

Then this profession were to be esteem'd.' (Doctor Faustus).

There is a striking resemblance between what Mephistopheles, Beelzebub and Lucifer set out to do with Faustus and what the authors of necromantic books are doing, as agents of devils, to present day children, wherein lies the vicious significance of trending readings.

\section{References}

[1] C. Marlowe. (1604). The Tragical History of Doctor Faustus. Ed. Alexander Dyce. Project Gutenberg EBook. Available: www.gutenberg.org/ebooks/779

[2] J. Milton. (1674). Paradise Lost. Produced by Judy Boss. Project Gutenberg EBook. Available: https://www.gutenberg.org/ebooks/26 
[3] D. Case. (2010). A Children's Book of Necromancy. Open Heart Publishing.

[4] Mzimba, Lizo, moderator. "Interview with Steve Kloves and J.K. Rowling" Archived 23 April 2011 at the Wayback Machine. BBC Newsround. February 2003. Retrieved 21 March 2006.

[5] "Doctor Faustus Essays: Critical Analysis of Faustus." 123HelpMe.com. 05 Oct 2019 <https://www.123helpme.com/view.asp?id=6004>. 